\title{
Antioxidant Activity of Melinjo Ketan (Gnetum gnemon L., 'Ketan') Seed Extract at Various Ripening Stages and Ethanol Solvent Concentration
}

\author{
Bambang Kunarto ${ }^{\# *}$, Sutardi Sutardi ${ }^{*}$, Supriyanto ${ }^{*}$, Chairil Anwar \\ ${ }^{\#}$ Department of Agricultural Product Technology, Faculty of Agricultural Technology, Semarang University, Semarang 50196, Indonesia. \\ E-mail: bambangkun@usm.ac.id \\ *Department of Food Science, Faculty of Agricultural Technology, Gadjah Mada University, Bulaksumur Yogyakarta 55281, Indonesia. \\ E-mail:sutardi@ugm.ac.id and supriyantoadi@ugm.ac.id \\ ${ }^{+}$Department of Chemistry. Faculty of Mathematics and Natural Science, Gadjah Mada University, Yogyakarta 55281, Indonesia, \\ Email: irilwar@yahoo.com
}

\begin{abstract}
Melinjo seeds (Gnetum gnemon L.) have the potency as antioxidants due to their bioactive compounds such as polyphenols, flavonoids, tannins, and resveratrol. The study was conducted to determine the effect of the ripening stages of Melinjo ketan variety seeds and ethanol solvent concentration on total of phenolic, flavonoid also resveratrol content, and antioxidant activity of Melinjo seed extract. The ripening stages of Melinjo seeds used were immature, semi-mature and mature. The ethanol solvent concentrations were $20 \%, 50 \%$ and $80 \%$. Samples of dried melinjo seeds were macerated in ethanol (1:5) at room temperature for 2 days. The extract was filtrated, evaporated and freeze-dried. This study reported that the ripening stages of melinjo seeds and ethanol solvent concentrations had effect on the total of phenolic, flavonoid, resveratrol content, and antioxidant activity of melinjo seed extract significantly $(p<0,05)$. Mature melinjo seeds macerated using $50 \%$ ethanol solvent produced extract with the highest antioxidant activity. It had the total phenolic content of $7.033 \pm 0.06 \mathrm{mg} \mathrm{GAE} / \mathrm{g}$, total flavonoids content of $335.04 \pm 1.32 \mathrm{mg}$ CE/100 g, resveratrol content of $1.55 \pm 0.3 \%$, DPPH radical inhibition of $66.07 \pm 0.38 \%$, and reducing power $(80.26 \pm 0.06 \%)$. These studies showed that the antioxidant effect of Melinjo ketan extract is influenced by the level of maturity and solvent concentrations of ethanol that can be an alternative of antioxidant sources. It is recommended to use Melinjo ketan seeds macerated with $50 \%$ ethanol solvent.
\end{abstract}

Keywords — antioxidant; melinjo ketan; resveratrol; ripening stage.

\section{INTRODUCTION}

Melinjo (Gnetum gnemon L.), including the family of Gnetaceae which is spread in Southeast Asia, especially in the territory of Indonesia. Mostly in Indonesia, melinjo's seeds and rinds are consumed as vegetables or snacks. Tatefuji et al. [1] states that melinjo seeds are not toxic and can be consumed in the long term. Melinjo seeds are oblong and have the size of $2.5 \times 1.5 \mathrm{~cm}$. There are several varieties of melinjo, which differ in the size of the fruit [2]. Melinjo ketan is one of the melinjo varieties. It has oval shaped. Its size is larger than melinjo kerikil, but smaller than melinjo gentong.

Previous studies investigated that melinjo seeds contain bioactive compounds such as polyphenols, flavonoids, tannins, and resveratrol. It indicates that melinjo seeds have the potential to be antioxidants source. Resveratrol $(3,5,4-$ trihydroxystilbene) is the compounds formed naturally from the types of polyphenols and phytoalexin [3]. Resveratrol has been reported to have antioxidant activity, anti-aging effects, anti-carcinogenic activity [4], hepato-protection [5], cardioprotection and neuroprotection [6,7], antiinflammatory activity [8], anti-obesity [9], and diabetes prevention activities [10]. Resveratrol is a group of hydroxyl having positions of 3,4 'and 5, aromatic rings and there are double bonds in resveratrol molecules, thus having a very strong ability in avert of free radicals [11]. Gerzon et al. [12] states that the elimination of the hydroxyl group or its suspension by cluster - OCH3 results in the loss of antioxidant properties in compounds. Based on the efficacy, the use of resveratrol as a bioactive agent in food and pharmaceuticals has been a concern [13]. It is expected that Melinjo ketan seed extract can be applied to food as an alternative to substitute synthetic antioxidants such as butylated hydroxytoluene, butylated hydroxytoluene 
Hydroxyanisol, propyl error and tert-butyl hydroxyl Quinone, because Synthetic antioxidants in food are not safe for consumers [14] [15].

The level of fruit ripening affects antioxidant activity as reported in several studies. The phenolic profile and antioxidant activity of lemons vary depending on different ripening stages [16]. The difference in harvest time of Pinot Noir and Merlot (Vitis vinifera L. cv.) grape berries significantly affects phenolic and physicochemical content [17]. Generally, the process of fruit ripening is consisting of changes of biochemical compound and primary \& secondary metabolism, which produce phytochemicals and nutrients that have the potency to improve health [18]. Blank et al. [19] states that the total phenolic, flavonoids and antioxidant activity of Bunchosia glandulifera seeds increased according to the level of its efficacy. The concentration of solvent influences the antioxidant activity as well. The general principle of extraction using solvents is "like dissolve like", that solvents extract phytochemicals only that have the same polarity as solvent [20].
The efficacy of melinjo ketan extraction based on the ripening stage is still unclear. Our study aimed to investigate the effect of ripening stages and ethanol solvent concentration to the phenolic total, flavonoid total, resveratrol content, and melinjo ketan seed extract antioxidant activity.

\section{MATERIAL AND METHOD}

\section{A. Materials}

Melinjo ketan seeds were obtained from Limpung district, Batang Regency, Central Java, Indonesia. Melinjo were harvested manually from several trees randomly. The fruits were selected become three stages of maturation according to age after flowering and external colour. Immature melinjo had green rind and was harvested at 60 days after flowering. Semi-mature melinjo had orange rind and was harvested at 68 days after flowering. While mature melinjo had red rind and was harvested at 75 days after flowering. The physical characteristics of melinjo ketan variety at various levels of maturity are shown in Table 1 and Figure 1.

TABLE I

Physical Characteristic Of Melinjo Ketan At Different Ripening Stages

\begin{tabular}{|c|c|c|c|}
\hline Characteristic & Immature & Semi-mature & Mature \\
\hline Age after flowering (days) & 60 & 68 & 75 \\
\hline Peels color & Green & Orange & Red \\
\hline Length $(\mathrm{cm})$ & $2,70 \pm 0,01$ & $2,71 \pm 0,05$ & $2,72 \pm 0,01$ \\
\hline Width $(\mathrm{cm})$ & $1,20 \pm 0,01$ & $1,21 \pm 0,01$ & $1,24 \pm 0,05$ \\
\hline Weight $(\mathrm{g})$ & $4,03 \pm 0,06$ & $4,07 \pm 0,06$ & $4,133 \pm 0,06$ \\
\hline
\end{tabular}

\section{B. Sample Preparation}

Melinjo ketan seeds were separated mechanically from the skin and shell, then freeze-dried. The freeze-dried melinjo seeds were reduced in size using a grinder and sifted to powder that passed the 40 mesh sieve. The powder sample was packaged in an airtight polyethylene plastic bag and stored until used at $4{ }^{\circ} \mathrm{C}$.

\section{Maceration}

Extraction of melinjo ketan seeds powder was carried out by maceration conducted to Kato et al. [21] with some modifications. One hundred gram of melinjo seed powder samples (immature, semi-mature and mature) were macerated in $500 \mathrm{ml}$ ethanol at room temperature for 2 days. The concentrations of ethanol solvent used were $20 \%, 50 \%$ and $80 \%$. Melinjo seed extract was filtered, then the filtrate was evaporated in vacuum until viscous. The viscous extract of melinjo seeds was freeze-dried at $-40^{\circ} \mathrm{C}$ and $10^{-1}$ torr. Furthermore, the freezed-dried extract of melinjo seeds obtained was stored in a dark place at $4{ }^{\circ} \mathrm{C}$ until it is ready to used for analysis.

\section{Analysis of Total Phenolic Content}

The melinjo seeds extract was analyzed to measure the total phenolic content by using the Folin-Ciocalteu assay according to Dewanto et al. [22] with few modifications. The $125 \mu \mathrm{l}$ of melinjo seed extract sample of were dissolved in $500 \mu \mathrm{l}$ of distilled water then add $125 \mu \mathrm{l}$ of FolinCiocalteu reagent solution until homogenized. Add $1.25 \mathrm{ml}$ of $\mathrm{Na}_{2} \mathrm{CO}_{3} 7 \%$, and distilled water was added to a volume of $3 \mathrm{ml}$. The absorbance measurement at $760 \mathrm{~nm}$ was carried out after incubation in the dark room for 90 minutes. The total phenolic content was expressed as mg Gallic Acid Equivalent (GAE) per gram of dry sample.

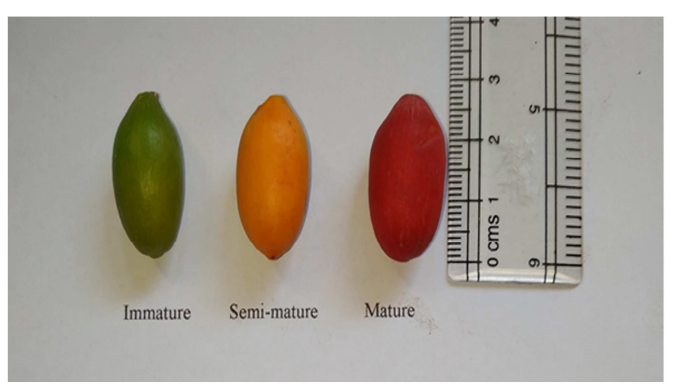

Fig. 1 Ripening stage of melinjo ketan 


\section{E. Total Flavonoid Content Analysis}

The total flavonoids of melinjo ketan seed extract were determined based on the method used by Zhishen et al. [23] and Bhat and Yahya [24]. The melinjo seed extract sample of $1 \mathrm{ml}$ was added with four $\mathrm{ml}$ of distilled water. At zero time, there was an addition of $0.3 \mathrm{ml}$ of $\mathrm{NaNO}_{2} 5 \%(\mathrm{w} / \mathrm{v})$. After 5 minutes, the solution was adding by $0.3 \mathrm{ml}$ of $\mathrm{AlCl}_{3}$ $10 \%(\mathrm{w} / \mathrm{v})$. The two $\mathrm{ml}$ of $1 \mathrm{M} \mathrm{NaOH}$ were added in the 6 th minute and the volume until $10 \mathrm{ml}$ by addition of distilled water. This mixture was vortex and the absorbance was analyzed by using a UV-visible spectrophotometer at 510 $\mathrm{nm}$. The results obtained were stated as mg Catechin Equivalents (CE) per $100 \mathrm{~g}$ of dry sample.

\section{F. Determination of Resveratrol Content}

A total of $0.1 \mathrm{ml}$ of melinjo seed extract was placed in the microtube, then added with $0.9 \mathrm{ml}$ of ethanol. The mixture was homogenized using vortex for 2 minutes and centrifuged for 5 minutes. The $20 \mu$ of extract was spotted into silica gel plate F254 and eluted in the mobile phase according to the mobile phase used by Liu et al. [25], namely toluene: ethyl acetate: acetic acid (15: 3 : 1$)$. The density was reading by TLC-scanner.

\section{G. DPPH Radicals Inhibition}

Antioxidant activity of melinjo seed extract was determined using DPPH assay according to Savic-Gajig at al. [26]. Melinjo seed extract was added by $1 \mathrm{ml}$ of DPPH solution. After mixing, it were incubated at room temperature for 30 minutes in less light conditions. The absorbance of the samples were quantified at $517 \mathrm{~nm}$. Antioxidant activity was stated as DPPH radicals inhibition (\%) and analyzed by using the equation 1 :

Inlibition of DPPI radicals ( $\%$ ) $=\frac{(A c-A s)}{A c} \times 100$

where Ac and As are absorbance of the control solution and absorbance of the samples treated with DPPH radicals, respectively.

\section{H. Reducing Power}

Reducing power was based on the method described by Ozcoy [27] with some modifications. The absorbance of the solution was measured at $700 \mathrm{~nm}$. The percentage of reducing power samples compared to the standard (ascorbic acid) was calculated using the following equation 2 .
Reducing powe: $(C)=\left[1-\left(1-\frac{A S}{A C}\right)\right] \times 100$

where Ac and As are standard absorbance and absorbance of the, respectively.

\section{Statistical Analysis}

The research design was used a randomized design with two factors and three repetitions. These factors were the ripening stages of melinjo seeds (immature, semi-mature, mature) and the concentration of ethanol solvents (20\%, $50 \%, 80 \%)$. The results were represented as mean values and standard deviations (SD). The statistical data analysis was performed by analysis of variance (ANOVA). If there were differences between treatments, then the analysis was continued with Duncan's multiple range test (DMRT) at the level of $5 \%$.

\section{RESULT AND DISCUSSION}

\section{A. Analysis of Total Phenolic Content}

The total phenolic content (TPC) of melinjo ketan seed extract at three different maturity levels (immature, semimature, and mature) and macerated with various ethanol concentrations is shown in Figure 2. The maturity level of melinjo seeds and ethanol solvents significantly affected $(\mathrm{P}<0,05)$ to the total phenolic content of the extract. Melinjo seeds with a higher maturity stage showed an increase in total phenolic extract. This is supported by previous study. Yang et al. [28] stated that maturity increases the total phenolic content of noni fruit. Mahmood [29] also reported that the more mature blueberries and mulberries showed an increasing total phenolic content.

The immature melinjo ketan seed extract had a lower total phenolic content than semi-mature and mature melinjo seed extract. It happened in the extract macerated at ethanol concentrations of $20 \%, 50 \%$ and $80 \%$. The total phenolic content of melinjo seed extracts macerated using $20 \%$ ethanol solvent were $1.70 \pm 0.006,1.83 \pm 0.05,4.13 \pm 0.16$ $\mathrm{mg} \mathrm{GAE} / \mathrm{g}$, respectively for immature, semi-mature and mature. Total phenolic content of immature, semi-mature and mature melinjo ketan seed extract macerated using $80 \%$ ethanol solvent were $3.24 \pm 0.05,3.41 \pm 0.31$, and $6.22 \pm$ $0.57 \mathrm{mg} \mathrm{GAE} / \mathrm{g}$, respectively.

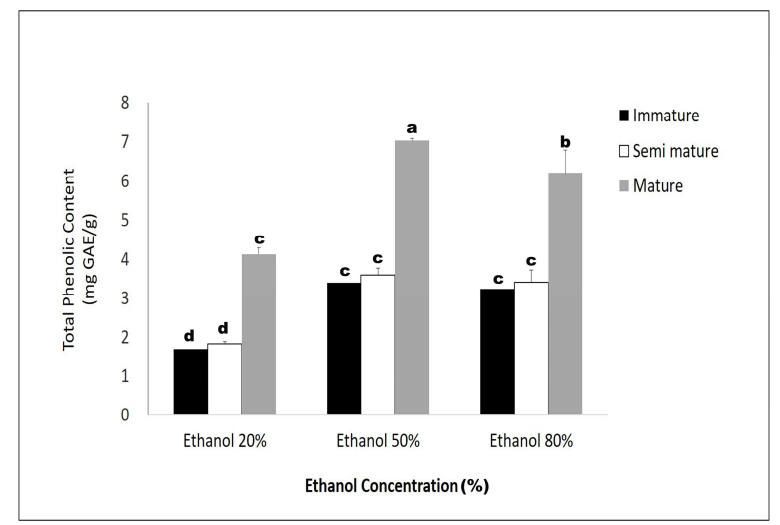

Fig. 2 Ripening stage of melinjo ketan seed extract 
Interestingly, mature melinjo ketan seed extract macerated using 50\% ethanol solvent had the highest total phenolic content production were $7.033 \pm 0.058 \mathrm{mg}$ GAE$/ \mathrm{g}$ extract. The maturation was increased enzyme activity for the Biosintesa phenol. The total increase of phenolic content in the mature stage can be caused by the higher production of phenylalanine ammonialyase [30]. The total phenolic content of melinjo seed extracts in this study are different from previous study. Bhat and Yahya [24] reported that TPC evaluated in melinjo ethanol extract was $15.1 \pm 2.19 \mathrm{mg}$ GAE/100g. In other study, Wazir at al. [31] reported that TPC melinjo seed extract ranged from 1.15 to $6.49 \mathrm{mg}$ GAE/g FDW. The difference of total phenolic occurred by several factors, including varieties, age, place and environmental conditions of melinjo growth and its cultivation.

\section{B.Total Flavonoid Content}

Maceration of melinjo ketan seeds with different ripening stages using various ethanol concentrations as solvents was produced extracts with significantly different of flavonoid $(p<0.05)$. The flavonoid content of melinjo seed extract also increased along with the maturity of melinjo seeds (Figure 3). The total flavonoid content of immature, semi- mature and mature melinjo ketan variety seed was extracted using $20 \%$ ethanol solvent were $199.21 \pm 0.12,200.40 \pm 0.26$, and $251.78 \pm 2.27 \mathrm{mg} \mathrm{CE} / 100 \mathrm{~g}$, respectively. While the total flavonoid content of melinjo extracts macerated using $80 \%$ ethanol solvents were $218.31 \pm 0.29,288.88 \pm 1.77$, and $296.79 \pm 1.94 \mathrm{mg} \mathrm{CE} / 100 \mathrm{~g}$, respectively for the immature, semi-mature, and mature. However, the highest total flavonoid content $(335.04 \pm 1.35 \mathrm{mg} \mathrm{CE} / 100 \mathrm{~g})$ was obtained from mature melinjo ketan variety seeds macerated using $50 \%$ ethanol.

The results of this study are in accordance with BettaiebRebey [32] which showed that the more mature cumin seed (Cuminum cyminum L.), the higher the flavonoids in it. Mahmood et al. [29] also stated that total flavonoids had increasing maturity in strawberry and mulberry from Pakistan. Moreover, Duma et al. [33] described bioactive compounds of tomatoes at various ripening stages and observed the increase in total flavonoids as maturity developed.

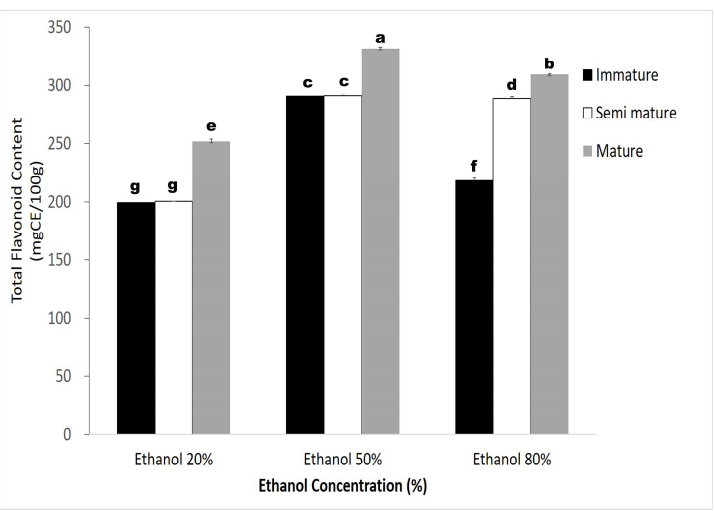

Fig. 3 Total flavonoid content of melinjo ketan seed extract

\section{Resveratrol Content}

Resveratrol is synthesized through the phenylalanine pathway. The stilbene synthase (STS), phenylalanine ammonia lyase (PAL), cinnamate-4-hydroxylase (C4H), and coumaroyl-CoA ligase (4CL) have important roles in the synthesis [34]. The synthesis of resveratrol is increased by the presence of wounds, infections, or stress. Various concentrations of ethanol solvents for maceration of melinjo seeds with different ripening stages showed an effect on the content of resveratrol significantly $(\mathrm{p}<0.05)$. The resveratrol content of immature, semi-mature and mature melinjo seeds macerated using $20 \%$ ethanol were $0.14 \pm 0.004,0.17 \pm 0.06$, and $0.54 \pm 0.02 \%$ (dry weight).

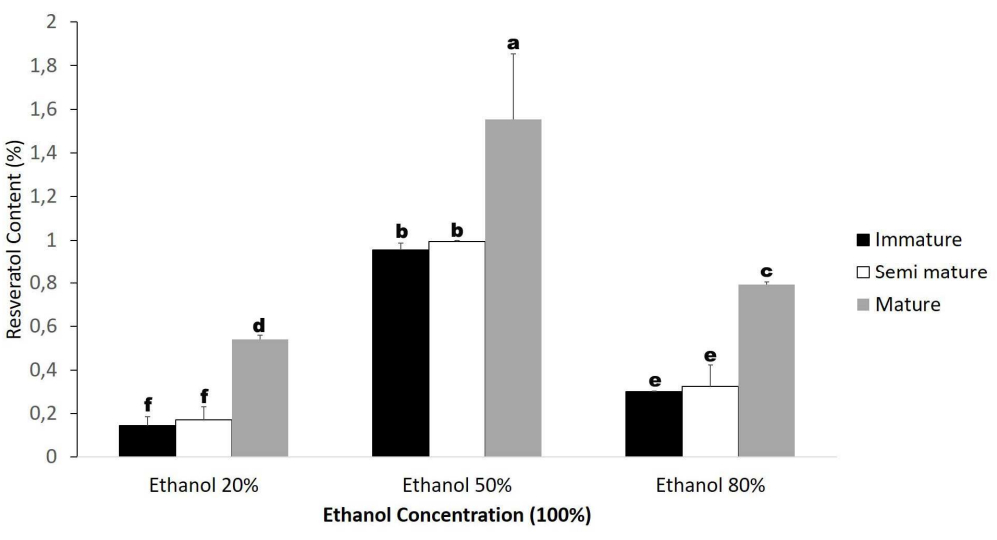

Fig. 4 Resveratrol content of melinjo ketan seeds extract 
Melinjo ketan seed extract using $80 \%$ ethanol had the resveratrol content of $0.3 \pm 0.001,0.32 \pm 1.00$, and $0.79 \pm$ $0.01 \%$ (dry weight), respectively for immature, semi-mature and mature melinjo seeds. The highest resveratrol content $(1.55 \pm 0.3 \%)$ was investigated in melinjo seeds extracts using 50\% ethanol (Figure 4). This study is consistent with Wang et al. [28] that mature strawberries seeds and pulp contained more resveratrol than immature strawberries. In addition, the use of $50 \%$ ethanol in maceration produced the highest resveratrol in melinjo seed extract compared with the use of $20 \%$ and $80 \%$ ethanol concentrations. This is in accordance with Kato et al. [21]. They extracted and isolated stilbenoid from melinjo seeds using $50 \%$ ethanol to obtain gnetin L, gnetin $\mathrm{C}$, gnemonoside $\mathrm{A}, \mathrm{C}, \mathrm{D}$, and resveratrol.

\section{Antioxidant Activity}

Plants have many groups of compounds that have antioxidant properties. Therefore determining antioxidant activity is difficult and requires a long time [24]. There are many developed method to determine antioxidant activity in plant material [36]. The methods should be capable of measuring the antioxidants to inhibit free radicals by lipid peroxidation or chelating metals inhibition. In this study, antioxidant activity assay of melinjo ketan variety seed extract was carried out using two commonly used methods of radical 2,2-diphenyl-1-picrylhydrazyl (DPPH) and reducing power. In the DPPH assay, a reaction occurs between antioxidants and free radicals (DPPH) which results in a reduction in DPPH concentration. It leads to color changes which can be measured at certain wavelengths.

In this study, DPPH radicals inhibition increased according to the maturity of melinjo seeds. DPPH radicals inhibition of melinjo ketan variety seed extract using $20 \%$ ethanol were $42.54 \pm 0.024,43.95 \pm 0.41$, and $45.37 \pm$ $0.29 \%$, respectively for immature, semi-mature, and mature melinjo seeds. The immature, semi-mature and mature melinjo ketan variety seed using $80 \%$ ethanol had DPPH radical inhibition of $45.43 \pm 0.29,42.19 \pm 0.88$, and $49.17 \pm$ $0.89 \%$, respectively. Interestingly, the highest DPPH radicals inhibition was obtained from mature melinjo seed macerated using 50\% ethanol (Figure 5). This study indicated that $50 \%$ ethanol solvents tended to be more effective in extracting antioxidant compounds

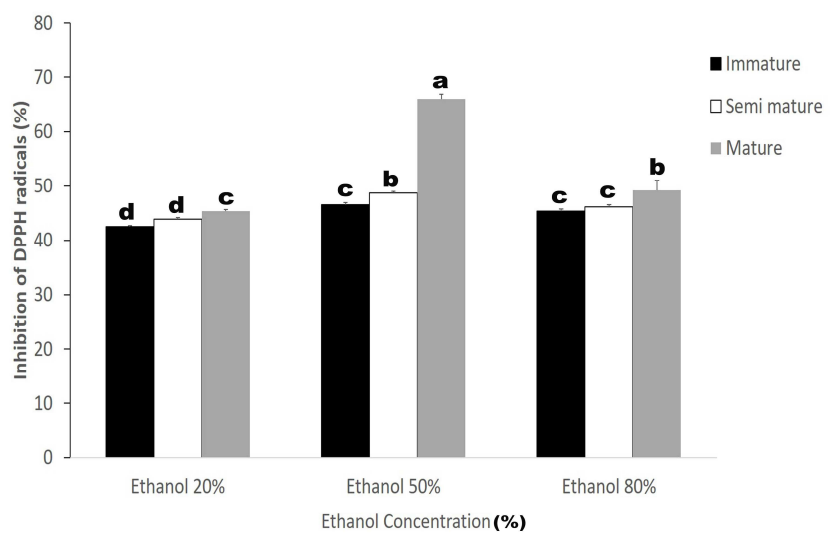

Fig. 5 Inhibition of DPPH radicals of melinjo ketan seed extract

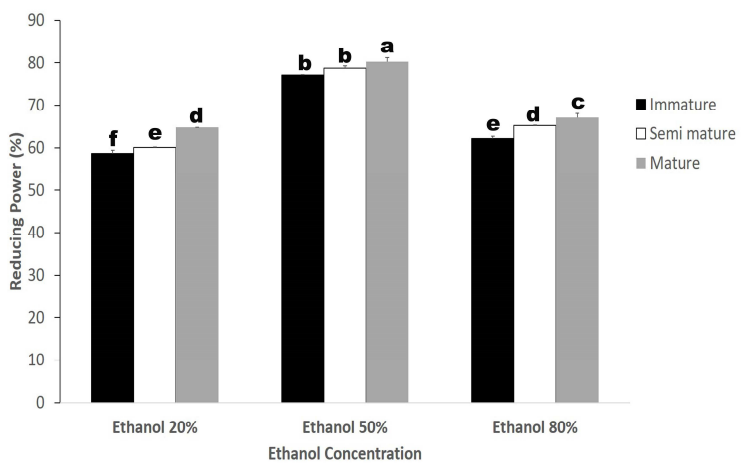

Fig. 6 Reducing power of melinjo ketan seed extracts

The reducing power method is according to the ability to reduce $\mathrm{Fe}^{3+}$ ions to $\mathrm{Fe}^{2+}$. The antioxidant activity is presented by the ability of melinjo seed extract to reduce these compounds. Reducing power from various extracts and standards (ascorbic acid) was using by potassium ferricyanide reduction. The highest reducing power (80.26 \pm
$0.06 \%$ ) was obtained from mature melinjo ketan variety seed extract macerated using 50\% ethanol as a solvent (Figure 6).

The antioxidant effect from extract of melinjo ketan variety was related to the total of phenolic, flavonoid, and resveratrol content. Increased of total phenolic content, total flavonoid content and resveratrol content in mature melinjo 
seed extract was followed by the increased of antioxidant activity. This is consistent with previous findings reported that phenolic compounds have high antioxidant capacity [37].

Atanassova et al. [38] found that flavonoids are responsible for the ability to counteract free radicals and chelate metal ions. The antioxidant activity of Polygonum equisetiforme extract also showed a relatively similar pattern with the total phenolic and flavonoids content [39]. Li et. al. [40] conducted a study of traditional Chinese herbal medicines. They investigated that flavonoids content in medical plants may be important phytochemical compounds as antioxidant. According to the previous study, the resveratrol has the ability as an antioxidant $[21,41]$.

\section{E. FTIR Spectroscopy}

The infrared spectrum represents a functional group. The infrared spectrum of melinjo ketan variety seed extracts at different maturity level had similarities. However, mature melinjo ketan variety seed macerated using $50 \%$ ethanol had a higher absorption intensity. The relationship between wave number, vibration band, and chemical compound is shown in Table 2. The infrared spectrum of melinjo seed extract using ethanol solvent is shown in Figure 7.

TABLE II

InfRaRed Vibrational Bands Of Melinjo Ketan SEeds Extract At Different Maturity Stages

\begin{tabular}{|l|l|l|}
\hline \multicolumn{1}{|c|}{$\begin{array}{c}\text { Wave number } \\
\left(\mathbf{c m}^{-1}\right)\end{array}$} & \multicolumn{1}{|c|}{$\begin{array}{c}\text { Vibration } \\
\text { band/group }\end{array}$} & Chemical compound \\
\hline $3297.31-3302.04$ & $\begin{array}{l}\text { OH stretch, H } \\
\text { bonded }\end{array}$ & Phenols, alcohols \\
\hline $2956.92-2959.43$ & C-H (Asym.) & Alkanes \\
\cline { 2 - 3 } & O-H Strech & Carboxylic acid \\
\hline $840.99-2847.85$ & C-H stretch (sym.) & Alkanes \\
\hline $1634.93-1644.86$ & $\begin{array}{l}\text { C=O stretch } \\
\text { (carbonyl) }\end{array}$ & $\begin{array}{l}\text { Flavonoids, } \\
\text { polyphenols }\end{array}$ \\
\cline { 2 - 3 } & C=C stretch & Aromatics \\
\hline $1407.88-1451.21$ & C-C stretch & Aromatics \\
\hline $1233.76-1265.14$ & C-N stretch & Aliphatic Amines \\
\hline $1015.01-1015.10$ & C-O stretch & $\begin{array}{l}\text { Alcohols, esters, } \\
\text { carboxylic acids }\end{array}$ \\
\cline { 2 - 4 } & C-OH stretch & Secondary alcohols \\
\hline
\end{tabular}
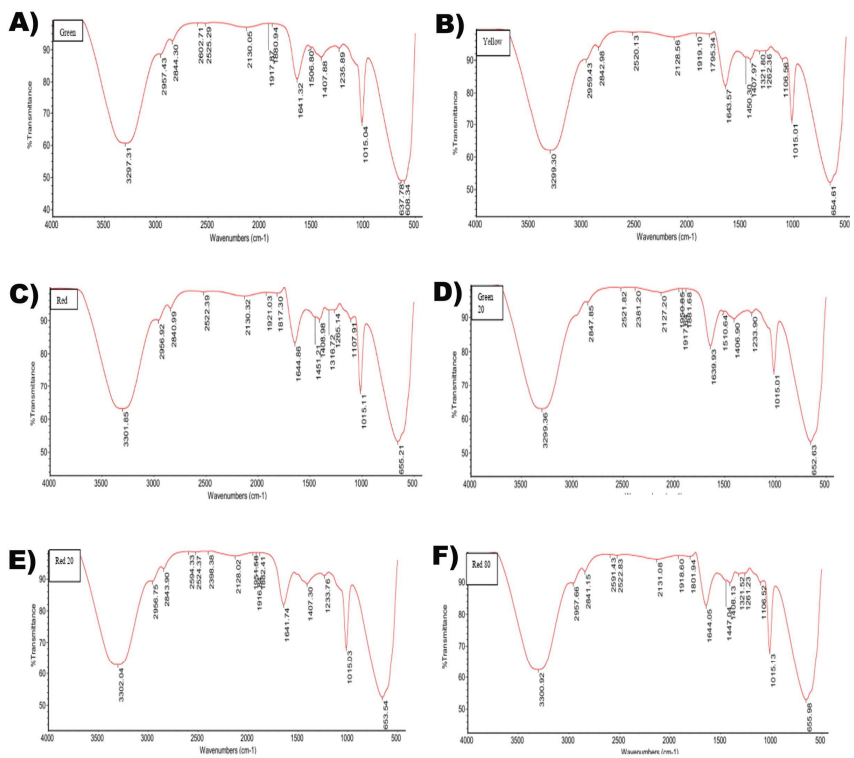

Fig. 7 The infrared spectra of melinjo ketan seed extract macerated using ethanol. A) Green (50\% ethanol), B) Orange (50\% ethanol), C) Red (50\% ethanol), D) Green (20\% ethanol), E) Red (20\% ethanol), F) Red (80\% ethanol). 


\section{CONCLUSIONS}

Melinjo ketan seeds may be an alternative of antioxidant sources. These results indicate that the antioxidant activity of melinjo ketan was influenced by the level of maturity and solvent concentrations of ethanol. Mature melinjo seeds macerated using 50\% ethanol solvent had the highest antioxidant activity.

\section{REFERENCES}

[1] T. Tatefuji, M. Yanagihara, S. Fukushima, and K. Hashimoto, "Safety assessment of melinjo (Gnetum gnemon L.) seed extract: Acute and sub chronic toxicity studies," Food and Chemical Toxicology, vol 67, pp 230-235, 2014.

[2] T. A. Siswoyo, "Physicochemical Characteristics Of Melinjo (Gnetum gnemon) Starch-Lipid,” Jurnal Ilmu Dasar, Vol. 5, No. 2, pp. 97-102, 2004

[3] W. Guo, A. Li, Z. Jia, Y. Yuan, H. Dai, and H. Li, "Transferrin modified PEG-PLA-resveratrol conjugates: in vitro and in vivo studies for glioma," Eur. J. Pharmacol., Vol. 718, pp. 41- 47, 2013.

[4] M. Elshaer, Y. Chen, X. J. Wang, and X. Tang, "Resveratrol: An overview of its anti-cancer mechanisms," Life Sci., Vol. 207, pp. 340-349, 2018

[5] C.W. Lee, F. L. Yen, H. W. Huang, T. H. Wu, H. H. Ko, W. S Tzeng, and C. C. Lin, "Resveratrol nanoparticle system improves dissolution properties and enhances the hepatoprotective effect of resveratrol through antioxidant and anti-inflammatory pathways, " $J$. Agric. Food Chem., Vol. 60, No. 18, pp. 4662-4671, 2012.

[6] P. E. B. Ferreira, E. J. Beraldi, S. C. Borges, M. R. M. Natali, and N. C. Buttow, "Resveratrol promotes neuroprotection and attenuates oxidative and nitrosative stress in the small intestine in diabetic rats,' Biomed Pharmacother, Vol. 105, pp. 724-733, 2018.

[7] Nakata, and H. H. Inoue, "Resveratrol and Cardiovascular Disease," Current Nutrition Reports, Vol. 3, No. 3, pp. 163-169, 2014.

[8] U. Svajger, and M. Jeras, "Anti-inflammatory effects of resveratrol and its potential use in therapy of immune-mediated diseases," Int Rev. Immunol., Vol. 31, No. 3, pp. 202-222, 2012.

[9] C. C. Chang, K. Lin, K. Peng, Y. Day, and L. Hung, "Resveratrol exerts anti-obesity effects in high-fat diet obese mice and displays differential dosage effects on cytotoxicity, differentiation, and lipolysis in 3T3-L1 cells," Endocrine Journal, Vol. 63, No. 2, pp. 169-178, 2016.

[10] M. M. M. Hussein, and M. K. Mahfouz, "Effect of resveratrol and rosuvastatin on experimental diabetic nephropathy in rats," Biomedicine \& Pharmacotherapy, Vol. 82, pp. 685-692, 2016.

[11] C. Iuga, J. R. Alvarez-Idaboy, and N. Russo, "Antioxidant activity of trans-resveratrol toward hydroxyl and hydroperoxyl radicals: a quantum chemical and computational kinetics study," The Journal of organic chemistry, 77 (8), pp. 3868-3877, 2012

[12] J. Gerszon, A. Rodacka, and M. Puchała, "Antioxidant properties of resveratrol and its protective effects in neurodegenerative diseases,." Advances in Cell Biology, 4 (2), pp. 97-117, 2014.

[13] G. Davidov-Pardo, and D. J. McClements, D. J., "Resveratrol encapsulation: Designing delivery systems to overcome solubility, stability and bioavailability issues," Trends in Food Science and Technology, Vol. 20, pp. 1-16, 2014.

[14] M. Aminzare, M. Hashemi, E. Ansarian, M. Bimkar, H. H. Azar, M. R. Mehrasbi, S. Daneshamooz, M. Raeisi, B. Jannat, and A. Afshari, "Using natural antioxidants in meat and meat products as preservatives: A review," Advances in Animal and Veterinary Sciences 7, pp. 417-426, 2019.

[15] S. A. Rege, and S. A. Momin, "Synergistic Antioxidant Activity of Clove Oleoresin with Capsicum Oleoresin and Kalonji Seeds Extract in Sunflower Oil.," International Journal of Nutritional Disorders \& Therapy, Vol. 1. 2018.

[16] X. Dong, Y. Hu, Y. Li, and Z. Zhiqin, 2019. "The maturity degree, phenolic compounds and antioxidant activity ofEureka lemon [Citrus limon (L.) Burm. f.]: A negative correlation between total phenolic content, antioxidant capacity, and soluble solid content," Scientia Horticulturae, Vol. 243, pp.281-289, 2019.

[17] Y. Zhou, P. Su, H. Yin, Z.Dong, L Yang, and C. Yuan, "Effects of different harvest times on the maturity of polyphenols in two red wine grape cultivars (Vitis vinifera L.) in Qingtongxia (China)," $S$. Afr. J. Enol. Vitic., Vol. 40, No. 1, 2018.

[18] Z. Zhang, D. Li, L. Wang, N. Ozkan, X. D. Chen, Z. Mao, and H. Yang, "Optimization of ethanol-water extraction of lignans from flaxseed," Separation and Purification Technology, Vol. 57, No. 1, pp. 17-24, 2007.

[19] D.E. Blank, D.E., D. Justen, S. Fraga, C. R. Peixoto, and N. F. de Moura, "Chemical Composition and Antioxidant Activity of Bunchosia glandulifera Fruit at Different Ripening Stages," Food and Nutrition Sciences, 9(10), pp.1147-1159, 2018.

[20] M. Oliveira, P. Bicudo, and R. H. Ribani, "Trust $\beta$-anthocyanins, phenolic acids and antioxidant properties of juçara fruits (Euterpe edulis M.) along the on-tree ripening process," Plant Foods Hum. Nutr., Vol. 69, pp. $142-147,2014$.

[21] E. Kato, Y. Tokunaga, and F. Sakan, "Stilbenoids isolated from the seeds of melinjo (Gnetum gnemon L.) and their biological activity," J. Agric. Food Chem., 57(6), pp. 2544-2549, 2009.

[22] V. Dewanto, X. Wu, K.K. Adom, and R. H. Liu, "Thermal processing enhances the nutritional value of tomatoes by increasing total antioxidant activity," Journal of agricultural and food chemistry, 50(10), pp. 3010-3014, 2002.

[23] J. Zhishen, T. Mengcheng, and W. Jianming, "The determination of flavonoid contents in mulberry and their scavenging effects on superoxide radicals," Food Chemistry, Vol. 64, pp. 555 - 559. 1999.

[24] R. Bhat, and B. N. Yahya, "Evaluating melinjau (Gnetum gnemon L.) seed flour quality as a base for development of novel food products and food formulations," Food Chemistry, Vol. 156, pp. 42 - 49. 2014.

[25] Y. Liu, L. Nan, J. Liu, H. Yan, D. Zhang, and X. Han, "Isolation and identification of resveratrol-producing endophytes from wine grape Cabernet Sauvignon," Springer Plus, Vol. 5, pp. 1-13, 2016.

[26] I. Savic-gajic, I.M. Savic, V. D. Nikolic, B. Nikolic, M. M. Popsavin, and S. J. Rakic, "The improvement of photostability and antioxidant activity of trans-resveratrol by cyclodextrins," Advanced Technologies, Vol. 6, No. 2, pp. 18-25, 2017.

[27] N. Ozsoy, A. Can, R. Yanardag, and N. Akev, "Antioxidant activity of Smilax excelsa L. leaf extracts," Food Chemistry, Vol. 110, pp. 571-583, 2008.

[28] J. Yang, R. Gadi, and Talene Thomson, "Antioxidant capacity, total phenols, and ascorbic acid content of noni (Morinda citrifolia) fruits and leaves at various stages of maturity," Micronesica, Vol. 41, No. 2, pp.167-176, 2011.

[29] T. Mahmood, F. Anwar, M. Abbas, and N. Saari, "Effect of maturity on phenolics (phenolic acids and flavonoids) profile of strawberry cultivars and mulberry species from Pakistan," Int. J. Mol. Sci., Vol. 13, pp. 4591-4607, 2012.

[30] I. B. Rebey, W. A. Wannes, S. B. Kaab, S. Bourgou, M. S. Tounsi, R. Ksouri, and M. L. Fauconnier, "Bioactive compounds and antioxidant activity of Pimpinella anisum L. accessions at different ripening stages, " Scientia Horticulturae 246, pp 453-461, 2019.

[31] D. Wazir, S. Ahmad, R. Muse, M. Mahmood, and M. Y. Shukor, "Antioxidant activities of different parts of Gnetum gnemon L.," Journal of Plant Biochemistry and Biotechnology, Vol. 20, No. 2, pp. $234-240,2011$.

[32] I. Bettaieb-Rebey, S. Kefi, S. Bourgou, I. Ouerghemmi, R. Ksouri, M.S. Tounsi, and B. Marzouk, "Ripening stage and extraction method effects on physical properties, polyphenol composition and antioxidant activities of cumin (Cuminum cyminum L.) seeds," Plant Foods for Human Nutrition, Vol. 69, pp. 358-364, 2014

[33] M. Dûma, I. Alsiòa, L. Dubova, and L. Erdberga, "Bioactive compounds in tomatoes at different stages of maturity," Proceedings Of The Latvian Academy Of Sciences. Section B, Vol. 72, No. 2, pp. 85-90. 2018. DOI: 10.2478/prolas-2018-0014.

[34] M. M. Hasan, and H. Bae, "An overview of stress induced resveratrol synthesis in grapes: perspectives for resveratrol-enriched grape product," Molecules, Vol. 22, pp. 294-312. 2017

[35] Y. S. Wang, C. Chen, Y. Chien, Wang, and P. Chen, "Resveratrol Content in Strawberry Fruit Is Affected by Preharvest Conditions," $J$. Agric. Food Chem., Vol. 55, pp. 8269-8274, 2007.

[36] C. Guo, J. Yang, J. Wei, Y. Li, J. Xu, and Y. Jiang, Y, "Antioxidant activities of peel, pulp and seed fractions of common fruits as determined by FRAP assay," Nutrition Research, Vol. 23, pp. $1719-1726,2003$.

[37] Y. Liu, Y. Qi, X. Chen, H. He, Z. Liu, Z. Zhanga, Y. Ren and $X$. Ren, "Phenolic compounds and antioxidant activity in red- and in green-fleshed kiwifruits," Food Research International, Vol. 116 pp. 291-301, 2019. 
[38] M. Atanassova, S. Georgieva, and K. Ivancheva, "Total phenolic and total flavonoid contents, antioxidant capacity and biological contaminants in medicinal herbs," Journal of The University of Chemical Technology and Metallurgy, Vol. 46, No. 1, pp. 81-88, 2011.

[39] M. Mahmoudi, F. Boughalleb, M. Mabrouk, N. Tlili, D. Potter, R. Abdellaoui, and N. Nasri, "Chemical analysis of the antioxidants from the aerial parts of wild Polygonum equisetiforme from Tunisia," Food Bioscience, Vol. 29, pp.24-39. 2019.
[40] M. Li, P. W. Pare, J. Zhang, T. Kang, Z. Zhang, D. Yang, K. Wang, and Hua, "Antioxidant capacity connection with phenolic and flavonoid content in Chinese medicinal herbs," Rec. Nat. Prod., Vol. 12, No. 3, pp. 239-250, 2018.

[41] I. Iliya, Z. Ali, T. Tanaka, M. Inuma, M. Furusawa, K. Nakayama, J. Murata, D. Darnaedi, N. Matsuura, and M. Ubukata, M., "Stilbene derivatives from Gnetum gnemon Linn.," Phytochemistry, Vol. 62, pp. 601-606, 2003. 